\title{
Change detection of burnaz dunes and prediction of environmental effects in iskenderun bay
}

\begin{abstract}
Iskenderun Bay is situated in the Eastern Mediterranean Region of Turkey which is important area for the biodiversity. Iskenderun Bay coastal zone of Turkey, especially Burnaz coastal dunes, are very rich biotopes. Unfortunately, these dunes are threatened by several land uses. The aim of this study is to monitor the coastal dunes between 1995 and 2015 and prediction of potential environmental effects because of land use changes. There are several methods for monitoring; in this study we used biotope mapping. Biotope maps were created for the two periods and the two maps were compared to determine changes in these dunes. As a result of this study, a few suggestions were presented on the ecological approach to maintain sustainability.
\end{abstract}

Keywords: iskenderun bay, biotope mapping, dunes, sustainability, change detection
Volume 2 Issue 5 - 2018

\author{
Aysel Gürkan, Aylin Salici, Mustafa Atmaca \\ Department of Landscape Architecture, Mustafa Kemal \\ University, Turkey
}

Correspondence: Aysel Gurkan, Department of Landscape Architecture, Mustafa Kemal University, Turkey, Tel +90 32622 I I4 12, Fax +90 32622 I 14 89, Email aysgmassur@hotmail.com

Received: November 01, 2017| Published: October 12, 2018

\section{Introduction}

"Land-change science has been emerged as a fundamental element of global environmental change and sustainability science". ${ }^{1}$ With increased availability and improved quality of multi-spatial and multitemporal remote sensing data as well as new analytical techniques, it is now possible to monitor land cover/land-use changes and urban sprawl in a timely and cost-effective way. ${ }^{2,3}$ Biotopes are generally described as a part or element of the environment that creates suitable conditions for living organisms to be nourished, to shelter, to protect one another, and to contact with each other, and can be limited according to their functional point of view. ${ }^{4,5}$ The conceptual basis is the classification of biotopes mainly based on land use and habitat type, as most habitats in urban areas have important social and economic functions, e.g. parks and school grounds. ${ }^{6-8}$ It is a fundamental variable that impacts on and links many parts of human and physical environments.,3 Biotope mapping should be based on a well-structured, fundamental concept that responds to different demands, especially maintenance and development of biodiversity and nature-like experiences for urban dwellers. ${ }^{9}$

The study employed in Burnaz dunes, located in Iskenderun Bay. Iskenderun Bay is located on the Eastern Mediterranean Region of Turkey. These dunes host very rich biotopes. "On the other hand, it is considered to be one of the most polluted shores of Turkey due to being a petroleum transfer harbor, and constant exposure to wastes of fertilizer factory, steel-iron factory, LPG factory, and other industrial and agricultural chemicals". ${ }^{10,11}$ These data show that these dunes came under pressure because of industrialization. Hence, the aim of this contribution is to monitor changes in the coastal landscape pattern of Burnaz dunes during a 20 years' time period between 1995 and 2015. The coastal zone changes were detected by rectified topographic maps of 1995 and 2015. The study was performed with the help of remote sensing and GIS mainly consists of three objectives: (1) to biotope map for two periods (1995 and 2015) (2) to quantify land use changes (3) to predict environmental problems that may arise because of land use changes in Iskenderun Bay.

\section{Materials and methods}

\section{Study area}

Iskenderun Bay is located on Eastern Mediterranean region of Turkey. The study area stretched from the Sarimazi beach on the northwest, and Burnaz stream on the west (east?) (Figure 1). The study area occupies approximately $882 \mathrm{Ha}$. Climate regime is Mediterranean climate characterized by a mild winter during the annual precipitation of $783.3 \mathrm{~mm}$ falls, and a hot dry summer. Average mean annual temperature is $19.6^{\circ} \mathrm{C}$, average maximum temperature is $23.8^{\circ} \mathrm{C}$, average minimum temperature is $15.6^{\circ} \mathrm{C}$ in İskenderun. ${ }^{12}$ Parent material consists mostly of conglomerate, calcaire and alluvial. Mediterranean vegetation consists of evergreen forest of Pinus brutia Ten., and shrub lands composed of maquis, and garrigue. ${ }^{3}$

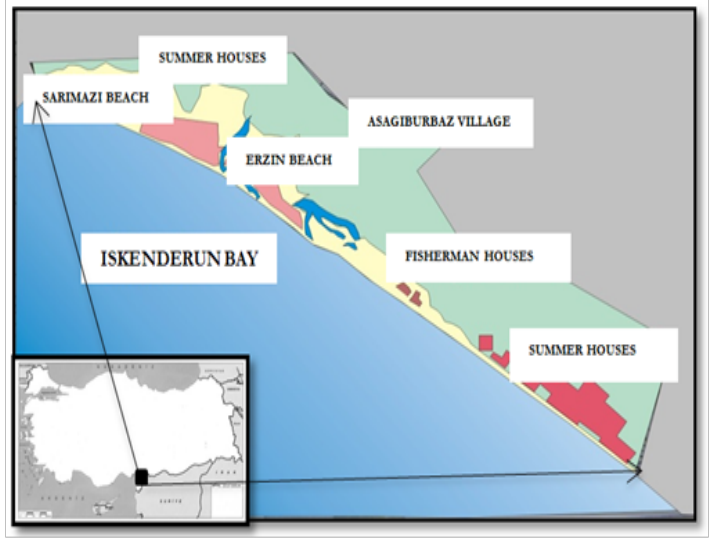

Figure I Location of study area.

\section{Methodology}

The study comprises 3 stages: (1) obtaining data and image preprocessing, (2) biotope mapping (3) landscape change analysis and prediction of environmental effects.

The first stage consisted of literature survey about the subject and obtaining spatial and non-spatial data. After that, topographic maps were digitized and geocoded to the UTM-WGS 84 zone 36 coordinate system. A minimum of 15 regularly distributed control point were selected from the images. The second stage consisted of biotope mapping of the two maps. Comprehensive biotope mapping was used, based on investigation of all biotopes, including natural and built-up areas. The biotope mapping requires knowledge of vegetation. ${ }^{13,14}$ Therefore, , the study performed by Guzelmansur and Altan, 2000 
is used to identify plant species. ${ }^{15}$ Additionally, field work was done in april and september 2015 for plant species analysis. The last stage involved landscape change analysis, based on image classification. Biotope mapping methods were applied using ArcGIS 10.1 for classification. Classified images were overlaid to extract landscape change information. Quantitative areal data of the overall land cover changes as well as gains and losses in each category between 1995 and 2015 were compared. In order to analyze the rate, and location of land cover changes, a set of 'gains' and 'losses' images for each category was produced. These 'change' images were converted into a raster format with the resolution of $0.5 \mathrm{~m}$. This GIS overlay was used to find landscape change information within the dunes.

\section{Results and discussion}

This section consists of two units; "Biotope mapping" and "Quantifying from to changes".

\section{Biotope mapping}

Images of 1995 and 2015 were preprocessed and classified to create biotopes maps. As a result of biotope mapping, eight types of biotopes are determined; wetland, settlement, agriculture, horticulture, forest (plantation area of Eucalyptus camaldulensis Dehnh.), sand hills, phrygana, industry (Figure 2) (Figure 3).

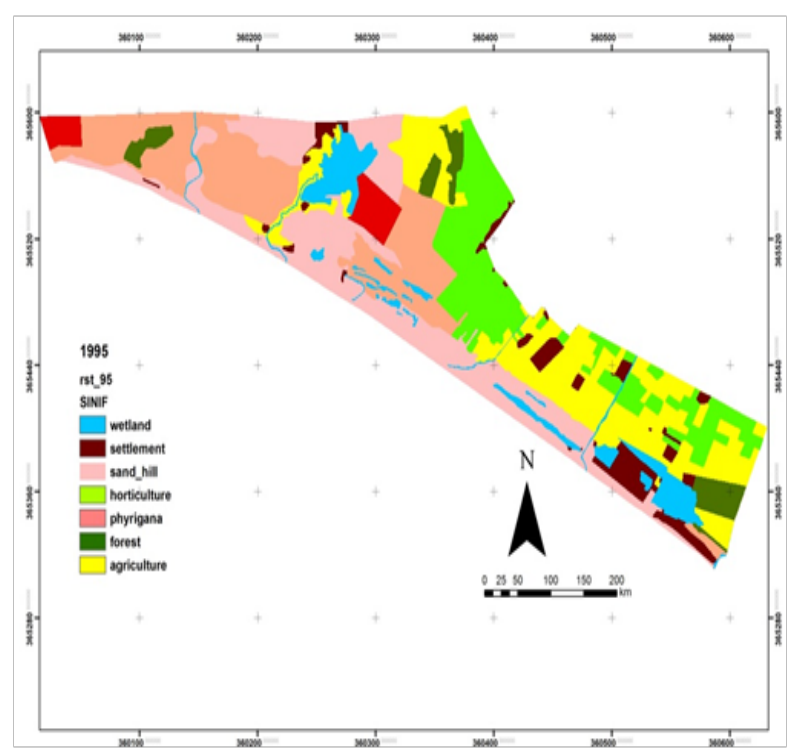

Figure 2 Biotope map of 1995.

Settlement: Lower Burnaz is the only village of the area. Burnaz beach and some summer houses were considered as settlement in the research area. Cultural plants like Morus alba L., Ficus carica L., Eucalyptus camaldulensis Dehnh., Platanus orientalis L., Nerium oleander L., Punica granatum L. var. nana, Washingtonia filifera (J. Linden ex Andre) H. Wendl, Salix babylonica L. and Acacia cyanophylla Lindl. are shown in these areas. ${ }^{15}$

Agriculture: Soils that have I and II land ability classes uses as agricultural purposes. Peanut is the most common species. The other agricultural species are watermelon, tomato, pepper, eggplant, cotton, etc.

Horticulture: Citrus sp. species grown in the horticulture area.
Forest: Eucalyptus camaldulensis Dehnh. is planted to reduce groundwater level in wetland area. Juncus acutus L. is the natural plant in these forests.

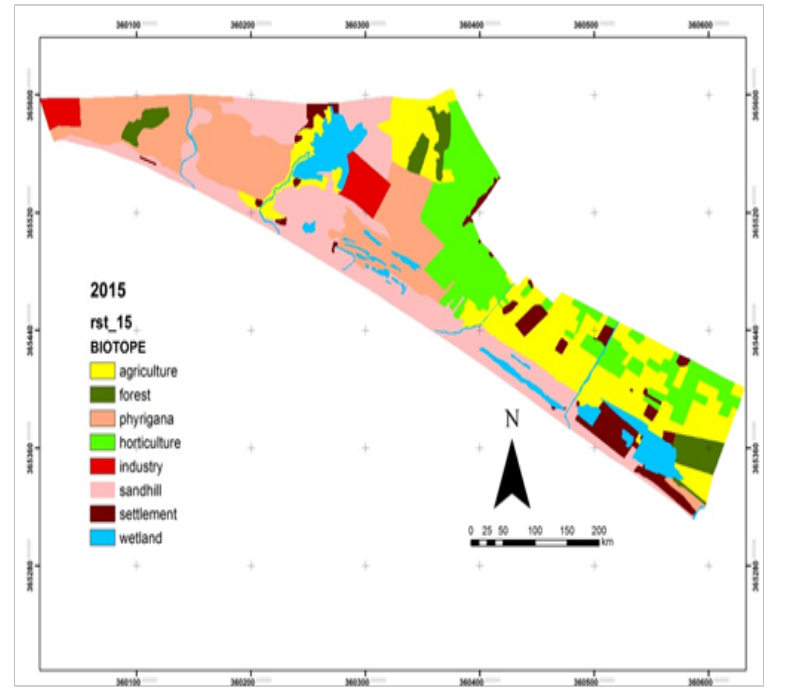

Figure 3 Biotope map of 2015.

Sand Hills: This biotope includes coastal dune vegetation. It takes place on the valve zone in the Mediterranean Sea and it the zone always interacted with the sea. Dominant species is Cakile maritime Scop. The other species are following; Euphorbia paralias L., Calamagrostis pseudophragmites (Haller F.) Koehler, Cakile maritime Scop., Myrtus communis L., Pistacia leutiscus L., Vitis vinifera L., Olea europaea L. var. sylvestris (Miller) Lehr., Laurus nobilis L., Jasminum fruticans L., Amigdalis sp., Paliurus spina-christi Miller, Pistacia terebinthus L., Spartium junceum L. Most common species area on the top of hills are; Helianthemum salicifolium (L.) Miller, Malva neglecta Wallr, Euphorbia terracina L., Senecio vernalis Waldst. et Kit., Echium plantagineum L., Osyris alba L., Paronychia argenta Lam. var. argenta, Gastridium phleoides (Nees et Meyen) C. E. Hubbard, Plantago lagopus L., Clematis vitalba L., Cutandia memohitica K. Richter, Lotus corniculatus L., Salvia sp., Parentucellia viscosa (L.) Caruel, Bromus diandrus Roth, Polygonum equisetiforme Sibth. Et Sm, Trigonella velutina Boiss., Trifolium campestre Schreb., Lolium temulentum L., Crepis setosa Hall. Fil., Ononis natrix L., Orobanche cernua Loefl., Scabiosa columbaria (L.), Lonicera etrusca Santivar. Hispidula Boiss, Medicago truncatula Gaertn. ${ }^{15}$

Phrygana: Phrygana consist of wetland area in the coastal zone. It is formed because of degraded coastal and wetland area. The following plant species are represent the biotopes; Silene colorata Poiret, Vulpia fasciculate (Forsskal) Fritsch, Anagallis arvensis L., Heliotropium europaeum L., Vaccaria hispanica (Mill.) Rauschert, Gastridium phleoides (Neeset Meyen) C. E. Hubbard, Trifolium physodes Stev. Ex Bieb., Avenaclauda Durieu, Plantago lanceolate L., Hordeum bulbosum L., Certaurea solstitialis L., Juncus acutus L., Typha domingensis Pers., Eucalyptus camaldulensis Dehnh., Crepis setosa Hall. Fil., Trachomitum venetum (L.) Woodson, Juncus acutus L., Erica manipuliflora Salisb., Anagallis arvensis, Inula viscosa (L.) Aiton, Trifolium campestre Schreb, Trachomitum venetum (L.) Woodson, Cyperus capitatus Vandelli, Vulpia fasciculate (Forsskal) Fritsch.

Industry: Industrial biotope formed after it transformed from site 
area to free trade area in the coastal zone. Power generation plant and natural gas exploration and filling area were constructed after the transformation to free trade zone.

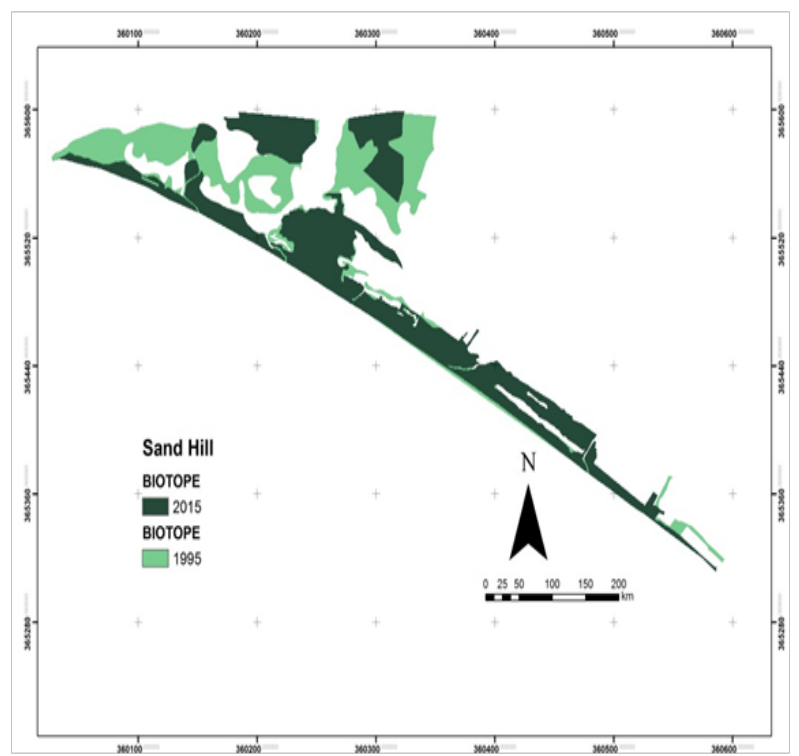

Figure 4 Land use changes for sand hill from 1995 to 2015.

\section{Quantification of changes}

In this study, landscape change analyses techniques were applied. It is the most obvious method of change detection, which requires the comparison of independently produced classified images.

Table I Land use/Land cover (LU/LC) of 1995 and 2015

\begin{tabular}{lllll}
\hline LU/LCType & I $995(\mathbf{H a})$ & I 995 (\%) & $\mathbf{2 0 1 5}(\mathbf{H a})$ & $\mathbf{2 0 1 5}(\%)$ \\
\hline Settlement & 19.07 & 3.75 & 26.97 & 4.95 \\
Agriculture & 198.75 & 39.11 & 115.82 & 21.29 \\
Horticulture & 13.65 & 2.69 & 85.58 & 15.73 \\
Forest & 8.38 & 1.65 & 21.96 & 4.04 \\
Sand hill & 116.7 & 32.8 & 124.14 & 22.82 \\
Wetland & 101.67 & 20.01 & 40.39 & 7.42 \\
Phrygana & 35.93 & 6.6 & 112.405 & 20.66 \\
Industry & 0 & 0 & 16.84 & 3.1 \\
Total & 508.22 & 100 & 508.22 & 100
\end{tabular}

Figure 2 and Figure 3 show the result maps of land cover of 1995 and 2015. These maps show land differences between two time points. The most prominent land use changes were observed in the horticulture and wetland areas. Horticultural land use increased from $2.69 \%$ to $15.73 \%$ in 20 years (Table 1). Agricultural area transformed to horticulture which does not have a negative effect to agricultural area. However, wetland areas decreased from $20.01 \%$ to $7.42 \%$. It is natural process of succession. Some wetland areas accrued as a result of excavation of sand areas. So, these areas transformed to phrygana. Sand hill decreased from $32.80 \%$ to $22.82 \%$, which causes negative effects to environment (Figure 4). Some of these areas transformed for industrial purposes. Industrial activities are forbidden because of the protected status of the coastal area in 1995, but after transformation to free trade area, some industries were constructed in the coastal zone. Industrial activities negatively effect the environment. It damages coastal zone by occupying sensitive areas. Additionally, it damages vegetation and fauna of the coastal zone. It also damage microclimate of these dunes due to hot water $\mathrm{c}$ and smoke from the factories.. Moreover, it damages the ground water because of factory wastewater.

\section{Conclusion}

The aim of the study was to monitor the changes of coastal dunes from 1995 to 2015, and determination of environmental effects in Iskenderun Bay, Burnaz Dunes. Comprehensive biotope mapping methods were used for monitoring changes in this study. The method has some advantages; it based on vegetation analysis which enforces us to collect all vegetation data from the study area. Therefore, it gives us the opportunity to collect all ecological data. The factor also necessitate to qualified labor about ecological data. On the other hand, collection of all ecological data has disadvantages such as difficulty to collect all ecological data in a restricted time period. The other difficulty is requirement of qualified labor about vegetation. Despite these disadvantages, biotope mapping is one of the best methods for monitoring ecologically sensitive areas.

Monitoring changes determined with help of GIS gives us the opportunity to comply easily with the maps if there is any new development. The coastal zone is sensitive to human disturbance. Industrial, agricultural and horticultural activities threaten the wildlife. The anthropogenic pressure is possible through the integration of ecological, social and economic systems.

Additionally, overfishing creates pressure on the sea and wetland fauna. Summer houses create pressure on the coastal dunes; vehicles can park in the coastal area which has a negative effect on the coastal vegetation and fauna. Planting of exotic plants like Washingtonia filifera (J. Linden ex Andre) $\mathrm{H}$. wendl in the coastal zone, may disrupt the natural structure. As a conclusion, these dunes are very important and very sensitive to human disturbance. The study show that dramatic changes occurred in the natural structure in the past 20 years. Anthropogenic pressure increased year by year. Only with a comprehensive action plan, the coastal area can be protected. It is very important to reduce the environmental effects for the Bay to maintain sustainability.

\section{Acknowledgements}

This research was carried out in the Geographic Information System Laboratory (GIS) of Mustafa Kemal University, Department of Landscape Architecture. We are thankful to the department. We are also grateful to Sabahattin Sakallı for assistance with GIS.

\section{Conflict of Interest}

The authors whose names are listed in the manuscript certify that they have NO affiliations with or involvement in any organization or entity with any financial interest (such as honoraria; educational grants; participation in speakers' bureaus; membership, employment, consultancies, stock ownership, or other equity interest; and expert testimony or patent-licensing arrangements), or non-financial interest (such as personal or professional relationships, affiliations, knowledge or beliefs) in the subject matter or materials discussed in this manuscript.

\section{References}

1. Rindfuss RR, Walsh SJ, Turner BL, et al. Developing a science of land change: challenges and methodological issues. Proc Natl Acad Sci USA. 2004;101(39):13976-13981. 
2. Yang C, Everitt J, Murden D. Evaluating high resolution SPOT 5 satellite imagery for crop identification. Comput Electron Agric. 2011;75(2):347-354.

3. Guzelmansur A, Kilic S. Land-cover classification using advanced land observation satellite imagery: a case study of the peri-urban region of Antakya, Turkey. J Food Agric Environ. 2013;11(2):1178-1181.

4. Foody GM. Status of land cover classification accuracy assessment. Remote Sens Environ. 2002;80(1):185-201.

5. Gürkan A. Biotope mapping in an urban environment for sustainable urban development- A case study in Southern part of Turkey. App Ecology Environ Resrch. 2016;14(4):493-504.

6. Sukopp H, Weiler S. Biotope mapping and nature conservation strategies in urban areas of the Federal Republic of Germany. Landsc Urban Plan. 1988;15(1-2):39-58.

7. Lövenhaft K, Bjorn C, Ihse M. Biotope patterns in urban areas: a conceptual model integrating biodiversity issues in spatial planning. Landsc Urban Plan. 2002;58(2-4):223-240.

8. Freeman C, Buck O. Development of an ecological mapping methodology for urban areas in New Zealand. Landsc Urban Plan. 2003;63(3):161-173.
9. Werner P. Why biotope mapping in populated areas. DEINSEA-Annual of the Natural History Museum Rotterdam. 1999;5:9-26.

10. Kargin F. Seasonal changes in levels of heavy metals in tissues of Mullus barbatus and Sparus aurata collected from Iskenderun Gulf (Turkey). Water Air Soil Pollut. 1996;90(3-4):557-562.

11. Kaya G, Turkoglu S. Bioaccumulation of heavy metals in various tissues of some fish species and green tiger shrimp (Penaeus semisulcatus) from Iskenderun Bay, Turkey, and risk assessment for human health. Biol Trace Elem Res. 2017;1(13):314-326.

12. https://tr.climate-data.org/location/26/

13. Hong SK, Song IJ, Byun B, et al. Applications of biotope mapping for spatial environmental planning and policy: case studies in urban ecosystems in Korea. Landsc Ecol Engi. 2005;1(2):101-112.

14. Gürkan A. Biotope mapping in landscape planning. Sustainable landscape planning and design. Leck, Germany: Printed by CPI books $\mathrm{GmbH}$; 2017:217-227.

15. Guzelmansur A, Altan T. Analysis of coast land use and alternative land use proposals for Erzin Sarımazı-Burnaz Beaches and some holiday house in coastal zone of Erzin. Çukurova University. J Agric Fac. 2000;16(3):85-94. 